\title{
FAKTOR-FAKTOR YANG MEMPENGARUHI PENGUNGKAPAN INFORMASI SOSIAL DALAM LAPORAN TAHUNAN PERUSAHAAN
}

\author{
Lia Safrina \\ STAI AI-Washliyah Banda Aceh \\ bohateintan@gmail.com
}

\begin{abstract}
The purpose of this research is to examine the effect of corporate characteristics,consist of size of board of commisioner, leverage, corporate size, profitability and ages of corporate to corporate social responsibility disclosure. This research can explain the decision making about the corporate social responsibility disclosure done by companies. This research used purposive sampling. The sample of this research is 16 companies. Researcher used multiple regression analysis as analysis method. The Result of this research shows that profitability have significant effect to corporate social responsibility disclosure. size of board of commisioner, leverage, corporate size and ages of corporate have not significant effect to corporate social responsibility disclosure. The Result of this research shows that size of board of commisioner, leverage, corporate size, profitability and ages of corporate have not significant effect to corporate social responsibility disclosure. That mean corporate social responsibility disclosure diseffect by five variables caused behaved the law of rule No. 40 year 2007 of limited shareholder that legalized on july 2007 section 74 that obligated to corporate to disclosure informatian social responsibility.
\end{abstract}

\section{Keywords : Corporate Characteristics, Corporate Social Responsibility Disclosure}

\begin{abstract}
Abstrak
Penelitian ini bertujuan untuk mengetahui apakah terdapat pengaruh dari karakteristik perusahaan yang diproksikan dalam ukuran dewan komisaris, leverage, ukuran perusahaan, profitabilitas dan umur perusahaan terhadap iumlah informasi sosial yang diungkapkan oleh suatu perusahaan. Penelitian ini dapat dijadikan sebagai tolak ukur pengambilan keputusan informasi social perusahaan pertambangan. Penelitian ini menggunakan metode purposive sampling, sampel yang digunakan berjumlah 16 perusahaan. Metode statistik yang digunakan dalam penelitian ini adalah analisis regresi berganda. Hasil dari penelitian ini menunjukan bahwa profitabilitas memiliki pengaruh yang signifikan terhadap jumlah informasi sosial yang diungkapkan oleh perusahaan, sedangkan ukuran dewan komisaris, leverage, ukuran perusahaan dan umur perusahaan tidak memiliki pengaruh yang signifikan terhadap jumlah informasi sosial yang diungkapkan oleh perusahaan. Hasil penelitian ini menunjukan bahwa secara simultan ukuran dewan komisaris, leverage, ukuran perusahaan, profitabilitas dan umur perusahaan tidak berpengaruh terhadap pengungkanpan informasi sosial perusahaan. Hal ini berarti bahwa pengungkapan informasi sosial
\end{abstract}


perusahaan tidak dipengaruhi oleh kelima variabel tersebut yang disebabkan oleh diberlakukannnya Undang-Undang Nomor 40 Tahun 2007 tentang Perseroan Terbatas (UU PT), yang disahkan pada 20 Juli 2007. Pasal 74 yang mewajibkan perusahaan mengungkapkan informasi sosialnya.

Kata kunci : Karakteristik Perusahaan, Jumlah Informasi Sosial yang Diungkapkan

\section{PENDAHULUAN}

Sejarah perkembangan akuntansi, yang berkembang pesat setelah terjadi revolusi industri di Inggris (1760-1860), menyebabkan pelaporan akuntansi lebih banyak digunakan sebagai alat pertanggungjawaban kepada pemilik modal (kaum kapitalis) sehingga mengakibatkan orientasi perusahaan lebih berpihak kepada pemilik modal. Berpihaknya perusahaan kepada pemilik modal mengakibatkan perusahaan melakukan eksploitasi sumber-sumber alam dan masyarakat (sosial) secara tidak terkendali sehingga mengakibatkan kerusakan lingkungan alam dan pada akhirnya mengganggu kehidupan manusia. Kapitalisme, yang hanya berorientasi pada laba material, telah merusak keseimbangan kehidupan dengan cara menstimulasi pengembangan potensi ekonomi yang dimiliki manusia secara berlebihan yang tidak memberi kontribusi bagi peningkatan kemakmuran mereka tetapi justru menjadikan mereka mengalami penurunan kondisi sosial.

Perusahaan dituntut untuk memberikan informasi mengenai aktivitas sosialnya.Sejauh ini perkembangan akuntansi konvensional (mainstream accounting) telah banyak dikritik karena tidak dapat mengakomodir kepentingan masyarakat secara luas.Tanggungjawab sosial diartikan bahwa perusahaan mempunyai tanggungjawab pada tindakan yang mempengaruhi konsumen, masyarakat, dan lingkungan.Tuntutan terhadap perusahaan untuk memberikan informasi yang transparan, organisasi yang akuntabel serta tata kelola perusahaan yang semakin bagus (good corporate governance) semakin memaksa perusahaan untuk memberikan informasi mengenai aktivitas

sosialnya. Masyarakat membutuhkan informasi mengenai sejauh mana perusahaan sudah melaksanakan aktivitas sosialnya sehingga hak masyarakat untuk hidup aman dan tentram, kesejahteraan karyawan, dan keamanan mengkonsumsi makanan dapat terpenuhi. Oleh karena itu dalam 
perkembangan sekarang ini akuntansi konvensional telah banyak dikritik karena tidak dapat mengakomodir kepentingan masyarakat secara luas, sehingga kemudian muncul konsep akuntansi baru yang disebut sebagai Social Responsibility Accounting (SRA) atau Akuntansi Pertanggungjawaban Sosial, yang menuntut diungkapnya informasi pertanggungjawaban sosial oleh perusahaaan.

Tanggung jawab sosial tidak lepas dari keberadaan perusahaan yang tidak akan pernah dapat melepaskan diri dari lingkungan sekitarnya, baik lingkungan sosial masyarakat lokal maupun lingkungan alam. Rusaknya kehidupan sosial masyarakat dan lingkungan alam dapat dipastikan akan mengganggu bahkan menghentikan proses produksi perusahaan, dan pada akhirnya akan menggagalkan maksimalisasi nilai keuntungan bagi para pemegang saham perusahaan itu sendiri. Kegagalan perusahaan untuk menjalankan tanggung jawab sosialnya dapat pula diartikan sebagai kegagalan dalam mencapai maksimalisasi nilai ekonomi perusahaan bagi pemegang saham, negara, dan masyarakat luas. Manfaat ekonomi dari keberadaan suatu perusahaan hanya akan berlangsung sesaat dan dirasakan secara sempit hanya oleh pemegang saham, sementara akibat negatif dari keberadaan perusahaan terhadap alam, lingkungan, masyarakat dan negara akan berlangsung sangat lama dan luas.

Fakta empiris yang melatarbelakangi dilakukannya penelitian ini adalah adanya realita kontradiktif, dimana di satu pihak ada perusahaan besar yang aktivitas usahanya banyak diwarnai dengan konflik sosial, berbagai konflik sosial yang terjadi dalam perusahaan yang diakibatkan oleh kegagalan perusahaan menjalankan tanggung jawab sosialnya, seperti demonstrasi dan protes yang menyiratkan ketidakpuasan beberapa elemen stakeholders pada manajemen perusahaan. Kasus yang lain sering muncul adalah protes dari berbagai elemen masyarakat sekitar lokasi pabrik yang merasa terganggu akibat limbah atau polusi yang timbul sehingga memberi dampak negatif bagi masyarakat sekitar seperti penarikan distribusi dan penghentian aktivitas produksi, mogok kerja massal karena karyawan menuntut perningkatan gaji dan kesejahteraan pekerja.

Tidak dapat di pungkiri bahwa aktivitas pertambangan dapat dipastikan juga menyebabkan rendahnya kualitas lingkungan sehingga banyak masyarakat 
yang protes atas pencemaran lingkungan akibat limbah atau polusi yang dilepas ke lingkungan, sehingga menyebabkan hubungan yang tidak harmonis antara perusahaan dengan lingkungan sosialnya. Untuk mengendalikan kerusakan lingkungan yang disebabkan oleh aktivitas perusahaan tambang tersebut maka diperlukan kontrol yang kuat dari seluruh stakeholder (perusahaan, pemerintah dan seluruh masyarakat).

Mengingat besarnya potensi negatif atas pertambangan maka tanggung jawab perusahaan untuk meminimalkan dampak negatif tersebut adalah dengan menyusun dokumen analisis dampak lingkungan, menyusun rencana pengelolaan lingkungan dan rencana pemantauan lingkungan yang juga di dalamnya terdapat program-program kepedulian bagi masyarakat sekitar pertambangan agar tidak hanya merasakan dampak negatif saja akan tetapi juga merasakan manfaat atas aktivitas pertambangan disekitarnya. Bentuk kepedulian perusahaan pertambangan adalah dengan mengembangkan Corporate Social Responcibility yang dapat memberikan manfaat langsung bagi masyarakat untuk meningkatkan kualitas hidupnya seperti penanggulangan kemiskinan, membantu dalam menyediakan fasilitas kesehatan, pendidikan, beasiswa, peningkatkan skill, peningkatan daya beli masyarakat sekitar pertambangan, memberikan pelatihan agar masyarakat sekitar pertambangan mempunyai daya saing, dan membantu membangun infrastruktur yang sangat diperlukan oleh masyarakat termasuk di dalamnya fasilitas air bersih.

Salah satu hal yang akan mendorong perusahaan harus mengungkapkan tanggungjawab sosial perusahaan adalah adanya regulasi pemerintah terhadap pengungkapan informasi sosial sejak tanggal 23 september 2007, Pengungkapan tanggung jawab sosial perusahaan (Corporate Social Responsibility) bukan lagi bersifat suka rela/komitmen yang dilakukan perusahaan didalam mempertanggungjawabkan kegiatan perusahaannya melainkan bersifat wajib/ menjadi kewajiban bagi beberapa perusahaan yang melakukan atau menerapkannya. Hal ini diatur dalam Undang-Undang Nomor 40 Tahun 2007 tentang Perseroan Terbatas (UU PT), yang disahkan pada 20 Juli 2007 Pasal 74 Undang-Undang Perseroan Terbatas menyatakan : (1) Perseroan yang menjalankan kegiatan usahanya di bidang dan/atau berkaitan dengan sumber daya alam wajib melaksanakan tanggungjawab sosial dan 
lingkungan (TJSL). (2) TJSL merupakan kewajiban Perseroan yang dianggarkan dan diperhitungkan sebagai biaya perseroan yang pelaksanaannya dilakukan dengan memperhatikan kepatutan dan kewajaran. (3) Perseroan yang tidak melaksanakan kewajiban dikenai sanksi sesuai dengan ketentuan peraturan perundang-undangan.

Dari uraian diatas peneliti ingin mengetahui sejauh mana perusahaan menunjukkan tanggungjawabnya terhadap kepentingan sosial dengan memberikan informasi sosial serta faktor-faktor yang mempengaruhi keputusan perusahaan untuk mengungkapkan informasi sosial didalam laporan tahunannya.

\section{METODOLOGI PENELITIAN}

Jenis penelitian yang dilakukan adalah penelitian asosiatif kausal. Menurut Sugiyono (2006:11) penelitian asosiatif kausal adalah penelitian yang bertujuan untuk menganalisis hubungan antara satu variabel dengan variabel lainnya atau bagaimana suatu variabel mempengaruhi variabel lain. Populasi penelitian ini adalah seluruh perusahaan pertambangan yang telah terdaftar (listing) di Bursa Efek Indonesia pada tahun 2009-2010. Metode pengambilan sampel yang digunakan Peneliti dalam penelitian ini adalah metode purposive sampling, yang mana peneliti menetapkan dua kriteria pengambilan sampel, yaitu:

1. Perusahaan-perusahaan yang menjadi sampel adalah perusahaan yang mempublikasikan laporan keuangan lengkap (termasuk catatan atas laporan keuangan) dan laporan tahunan melalui situs Bursa Efek Indonesia.

2. Perusahaan-perusahaan yang menjadi sampel adalah perusahaan yang mengungkapkan informasi sosial melalui laporan tahunannya.

Perhitungan indeks tingkat pengungkapan tanggung jawab sosial perusahaan diukur dengan rasio total skor yang diperoleh dengan skor maksimal yang dapat diperoleh. Skor maksimal tiap-tiap blok berbeda sesuai penyesuaian yang telah dilakukan pada masing-masing blok. Indeks diformulasikan sebagai berikut ini. 


$$
\text { INDEKS }=\frac{n}{k}
$$

Notasi:

$\mathrm{n}=$ jumlah skor pengungkapan yang diperoleh

$\mathrm{k}=$ jumlah skor maksimal

Data yang dikumpulkan dalam penelitian ini berupa data kuantitatif, yaitu data yang diukur dalam suatu skala numerik. Sumber data penelitian ini merupakan data sekunder, berupa laporan keuangan dan laporan tahunan yang dipublikasikan di Pusat Referensi Pasar Modal Bursa Efek Indonesia

Pengungkapan informasi sosial masing-masing perusahaan dalam laporan tahunan pada perusahaan-perusahaan yang menjadi sampel dalam penelitian ini dihitung berdasarkan indeks. Menghitung indeks pengungkapan informasi sosial digunakan metode dikotomi, dimana jika suatu item diungkapkan diberi nilai satu dan jika tidak diungkapkan diberi nilai nol. Skor yang diperoleh tiap perusahaan selanjutnya akan dijumlahkan untuk memperoleh skor total, yang selanjutnya dibagi dengan total skor yang diharapkan dapat diperoleh oleh perusahaan (skor maksimal). Perhitungan indeks pengungkapan informasi sosial dilakukan sesuai dengan kategori informasi sosial menurut Ahmed dan Zhegal dalam harahap (2001:363) yaitu yang meliputi: lingkungan (link), energy, praktek bisnis yang wajar, sumber daya manusia (SDM) dan produk.

Metode penelitian yang digunakan dalam menyusun penelitian ini adalah penelitian kuantitatif yang memiliki tujuan untuk menguji atau verifikasi teori, meletakkan teori secara deduktif menjadi landasan dalam penemuan dan pemecahan masalah penelitian. Dalam menganalisis data peneliti menggunakan:

\section{Analisis regresi}

Setelah mendapatkan data-data yang dibutuhkan dalam penelitian ini, peneliti akan melakukan serangkaian tahap untuk menghitung dan mengolah data-data tersebut agar dapat mendukung hipotesis yang telah diajukan. 
Teknik regresi linier berganda dilakukan terhadap model yang diajukan peneliti dengan menggunakan bantuan program Eviews.4 untuk memprediksi hubungan antara variabel independen dengan variabel dependen yang diukur dengan rumus:

$$
Y=a+b_{1} x_{1}+b_{2} x_{2}+b_{3} x_{3}+b_{4} x_{4}+b_{5} x_{5}+e i
$$

Dimana:

$$
\begin{array}{ll}
\mathrm{Y} & =\text { Indeks Pengungkapan Informasi Sosial } \\
\mathrm{X}_{1} & =\text { Ukuran dewan komisaris } \\
\mathrm{X}_{2} & =\text { Tingkat leverage } \\
\mathrm{X}_{3} & =\text { Ukuran perusahaan } \\
\mathrm{X}_{4} & =\text { Profitabilitas } \\
\mathrm{X}_{5} & =\text { Umur perusahaan } \\
\mathrm{a} & =\text { Konstanta } \\
\mathrm{b} & =\text { Koefisien regresi } \\
\mathrm{ei} & =\text { Error term }
\end{array}
$$

\section{Uji Asumsi Klasik}

Sebelum dilakukan pengujian hipotesis dengan menggunakan analisis regresi linear berganda, maka diperlukan pengujian asumsi klasik yang meliputi:

\section{a. Uji Normalitas}

Uji Pengujian ini dimaksudkan untuk mengetahui apakah dalam model regresi, Variabel pengganggu atau residual mempunyai distribusi normal atau tidak. Dalam penelitian ini untuk menguji normalitas variabel menggunakan jarque-bera test. Menurut Winarno (2007:135) "Jarque-Bera test adalah uji statistik untuk mengetahui apakah data terdistribusi normal, dan untuk mengukur Jarque-Bera test dengan mencari perbedaan skewness dan kurtosis. Uji Jarque-Bera didistribusi dengan degree freedom sebesar 2. Data berdistribusi normal juga dapat dilihat dari nilai probabilitas yang tidak signifikan (>0.05)."

\section{b. Uji Multikolinearitas}


Menurut Santoso (2002:207), Linearitas ini berarti bahwa antar variabel independen yang terdapat dalam model memiliki hubungan sempurna atau mendekati hubungan sempurna (koefisien korelasinya tinggi atau bahkan1). Model regresi yang baik seharusnya tidak terjadi multikolinearitas. Berdasarkan Gujarati (2003:359) Uji multikolinieritas dapat dilakukan dengan melihat nilai uji auxiliary regression, yaitu membandingkan nilai $R^{2}$ model utama dengan regresi parsial dari masing-masing variabel bebasnya, Jika nilai $R^{2}$ parsial dari masingmasing variabel bebas lebih tinggi dari $R^{2}$ model utama, dalam model regresi terjadi penyimpangan asumsi klasik multikolinieritas dan jika nilai $R^{2}$ utama lebih besar dari $R^{2}$ kedua dan seterusnya berarti tidak terjadi masalah multikolinearitas.

\section{c. Uji Heteroskesdastisitas}

Menurut Ghozali (2001:69) Uji heteroskedastisitas bertujuan menguji apakah dalam model regresi terjadinya perbedaan varians residual suatu pengamatan ke pengamatan yang lain. Jika varians tetap maka disebut homokesdatisitas dan jika berbeda maka terjadi problem heteroskedastisitas. Menurut Gujarati (2003:388) mengatakan bahwa "Model regresi yang baik adalah homokesdatisitas atau tidak terjadi heteroskedastisitas." Untuk mendeteksi heteroskedastisitas dalam penelitian ini menggunakan white's general heteroscedasticity test, jika nilai Obs. R-squared tidak signifikan maka data tidak terjadi heteroskedastisitas.

\section{d. Uji Autokorelasi}

Menurut Ghozali (2001:70) Autokorelasi adalah korelasi antar sesama urutan pengamatan dari waktu ke waktu. Menurut Gujarati (2003: 442) "Autokorelasi ini dominan terjadi pada data time series". Pendeteksian terhadap penyimpangan asumsi klasik untuk autokorelasi dalam penelitiSan ini dilihat pada besarnya nilai Breusch-Godfrey Test. Jika nilai Obs.R-squared tidak signifikan maka data tidak terjadi autokorelasi. 


\section{PEMBAHASAN}

\section{Pengujian Asumsi Klasik}

Analisa dilakukan dengan model analisa regresi berganda. Sebelum dilakukan uji hipotesis, peneliti akan melakukan uji asumsi klasik. Pengujian ini perlu dilakukan untuk mengetahui apakah distribusi data yang digunakan dalam penelitian ini berdistribusi normal, serta bebas dari gejala multikolinearitas, heteroskesdasitas serta autokorelasi.

\section{a. Uji normalitas}

Pengujian ini dimaksudkan untuk mengetahui apakah dalam model regresi, variabel pengganggu atau residual mempunyai distribusi normal, pengujian normalitas diuji berdasarkan uji jarque-berra, yang hasilnya tampak pada gambar 4.1 berikut:

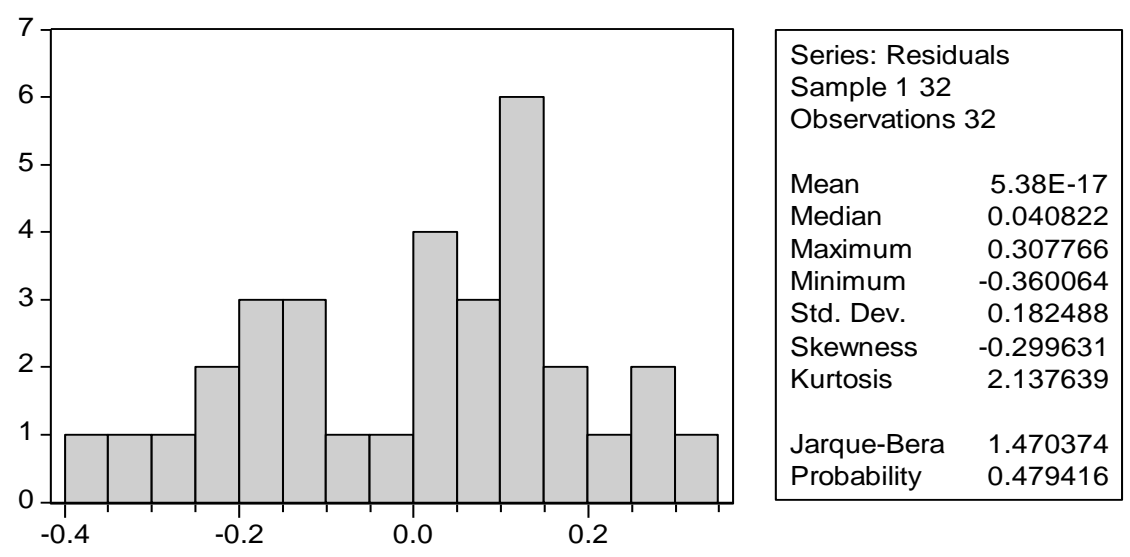

Sumber : data diolah (2011)

Gambar 4.1. Uji Normalitas data

Berdasarkan gambar 4.1 dapat dilihat bahwa nilai jarque-berra 1.4703 dengan nilai probabilitas tidak signifikan 0.47 , berarti bahwa data yang digunakan dalam penelitian ini memenuhi asumsi normalitas.

\section{b. Uji multikolinearitas}

Multikolinearitas adalah situasi dimana terdapat korelasi antara variabel variabel bebasnya. Uji ini menentukan apakah pada model 
regresi ditemukan adanya korelasi antar variabel bebas. Dalam uji ini dilakukan pendeteksian terlebih dahulu, kemudian jika hal tersebut terjadi, barulah dilakukan tindakan (treatment) untuk menghilangkan efek dari multikolinearitas. Uji multikolinieritas dalam penelitian ini dilakukan dengan melihat nilai uji auxiliary regression, yaitu membandingkan nilai $R^{2}$ model utama dengan regresi parsial dari masing-masing variabel bebasnya. Jika nilai $R^{2}$ parsial dari masing-masing variabel bebas lebih tinggi dari $R^{2}$ model utama, dalam model regresi terjadi penyimpangan asumsi klasik multikolinieritas (Gujarati 2003:359). Hal ini dapat dilihat pada tabel 4.4 berikut.

Tabel 4.4. Uji Multikolinearitas

\begin{tabular}{|c|c|}
\hline Koefisien Determinasi & $\begin{array}{c}\text { Nilai Koefisien } \\
\text { Determinasi }\end{array}$ \\
\hline $\mathrm{R}_{1}{ }^{2}$ & 0.29 \\
\hline $\mathrm{R}_{2}{ }^{2}$ & 0.13 \\
\hline $\mathrm{R}_{3}{ }^{2}$ & 0.07 \\
\hline $\mathrm{R}_{4}{ }^{2}$ & 0.00001 \\
\hline
\end{tabular}

Sumber : data diolah (2011)

Berdasarkan tabel $4.4 \mathrm{di}$ atas terlihat bahwa nilai koefisien determinasi pertama $\left(\mathrm{R}_{1}{ }^{2}\right)=0.29$ lebih besar dari koefisien kedua $\left(\mathrm{R}_{2}{ }^{2}\right)=$ 0.13 , ketiga $\left(R_{3}{ }^{2}\right)=0.07$ dan keempat $\left(R_{4}{ }^{2}\right)=0.00$ yang berarti bahwa data yang digunakan dalam penelitian ini bebas multikolinearitas.

\section{c. Uji Heteroskesdisitas}

Uji heteroskedastisitas bertujuan menguji apakah dalam model regresi terjadinya perbedaan varians residual suatu pengamatan ke pengamatan yang lain. Jika varians tetap maka disebut homokesdatisitas dan jika berbeda maka terjadi problem heteroskedastisitas.Model regresi yang baik adalah homokesdatisitas atau tidak terjadi heteroskedastisitas. Untuk mendeteksi heteroskedastisitas dalam penelitian ini menggunakan 
white's general heteroscedasticity test, jika nilai Obs. R-squared tidak signifikan maka data tidak terjadi heteroskedastisitas. Hal ini dapat dilihat pada tabel 4.5 berikut.

Tabel 4.5. Uji Heteroskedastisitas

\begin{tabular}{|c|c|c|c|}
\hline F-statistic & 5.120956 & Probability & 0.00399 \\
& & & 2 \\
\hline Obs ${ }^{*}$-squared & 28.89647 & Probability & 0.08981 \\
& & & 8 \\
\hline
\end{tabular}

Sumber: data diolah (2011)

Dari tabel di atas dapat dilihat bahwa nilai Obs. $R$-squared 28.89647 dan nilai probabilitas tidak signifikan yaitu: 0.089 yang berarti bahwa penelitian ini bebas dari masalah heteroskedastisitas.

\section{d. Uji Autokorelasi}

Uji ini bertujuan untuk melihat apakah dalam model linear ada korelasi antar kesalahan pengganggu pada periode $t$ dengan kesalahan periode $t-1$ (sebelumnya). Model regresi yang baik adalah yang bebas dari autokorelasi.untuk mendeteksi masalah dalam autokorelasi peneliti menggunakan uji Durbin Watson (DW) atau dengan melihat breuschgodfrey test, jika nilai probabilitas Obs.R-squared tidak signifikan maka penelitian ini bebas dari masalah autokorelsasi. Hal ini dapat dilihat pada tabel 4.6 berikut.

Tabel 4.6. Uji Autokorelasi

\begin{tabular}{|c|c|c|c|}
\hline F-statistic & $2.31 \mathrm{E}-07$ & Probability & 0.999620 \\
\hline Obs $^{\star}$ R-squared & $2.47 \mathrm{E}-07$ & Probability & 0.999604 \\
\hline
\end{tabular}

Sumber: data diolah (2011)

Dari tabel diatas dapat dilihat bahwa nilai Obs.R-squared 2.47 dengan nilai Probabilitas yang tidak signifikan 5\% Yaitu 0.999, Hal ini berarti bahwa tidak terjadi autokorelasi dalam regresi ini. 


\section{Pengujian Hipotesis}

\section{a. Uji Koefisien Determinasi $\left(\mathbf{R}^{2}\right)$}

Koefisien determinasi (Goodness of fit), yang dinotasikan dengan $\mathrm{R}^{2}$ merupakan suatu ukuran yang penting dalam regresi. Determinasi $\left(R^{2}\right)$ mencerminkan kemampuan variabel dependen. Tujuan analisis ini adalah untuk menghitung besarnya pengaruh variabel independen terhadap variabel dependen. Nilai $\mathrm{R}^{2}$ menunjukkan seberapa besar proporsi dari total variasi variabel tidak bebas yang dapat dijelaskan oleh variabel bebas. Pada penelitian ini untuk melihat koefisien determinasi antara variabel independen dan dependen dapat dilihat nilai $\mathrm{R}$-squared pada tabel 4.7 berikut.

Tabel 4.7. Uji Koefisien Determinasi $\left(R^{2}\right)$

\begin{tabular}{|c|c|}
\hline Nilai R Square & Persentase \\
\hline 0.20 & $20 \%$ \\
\hline
\end{tabular}

Sumber: Data diolah (2011)

Dari tabel diatas menunjukan nilai $R^{2}=0.20$, yang berarti bahwa kelima variabel dependen dalam penelitian ini yaitu: ukuran dewan komisaris, tingkat leverage, ukuran perusahaan, profitabilitas dan umur perusahaan dapat menjelaskan $20 \%$ pengaruh dari jumlah informasi sosial yang diungkapkan. Adapun sisanya dijelaskan oleh sebab-sebab lain diluar model.

\section{b. Uji Signifikansi Simultan (Uji F)}

Signifikansi model regresi secara simultan diuji dengan melihat nilai probabilitas signifikansi dari $F$, dimana jika nilai signifikansi dibawah 0,05 maka variabel independen dinyatakan berpengaruh terhadap variabel dependen. Adapun hipotesis untuk uji $\mathrm{F}$ adalah sebagai berikut:

$\mathrm{H}_{1}$ : Ukuran dewan komisaris, tingkat leverage, ukuran perusahaan, profitabilitas dan umur perusahaan memiliki pengaruh secara simultan terhadap jumlah informasi sosial yang diungkapkan. 
Nilai probabilitas signifikansi dari F dapat dilihat pada tabel 4.8 berikut ini.

Tabel 4.8. Uji Signifikansi Simultan (Uji F)

\begin{tabular}{|c|c|}
\hline F-statistic & 1.305575 \\
\hline Probalitas (F-statistic) & 0.292212 \\
\hline
\end{tabular}

Sumber: Data diolah (2011)

Dari hasil analisis regresi ini menunjukan bahwa $F_{\text {hitug }}=1.305575$ dan probabilitas signifikansi uji tersebut sebesar 0.2922 yang berarti lebih besar dari 0,05 yang menunjukan bahwa variabel bebas secara bersama-sama tidak memiliki pengaruh yang signifikan terhadap jumlah informasi sosial yang diungkapkan perusahaan. Hasil analisa statistik menunjukkan bahwa secara simultan variabel ukuran dewan komisaris, tingkat leverage, ukuran perusahaan, profitabilitas dan umur perusahaan secara bersama-sama tidak memiliki pengaruh yang signifikan terhadap jumlah informasi sosial yang diungkapkan perusahaan dengan nilai probabilitas $F_{\text {hitung }}$ sebesar 0.2922 yang lebih besar dari 0.05 . Dengan demikian, berdasarkan hasil penelitian menolak $H_{1}$ dan menerima $\mathrm{H}_{0}$. Hasil penelitian ini tidak sesuai dengan penelitian Sembiring (2005), Sitepu (2007), Rosmasita (2007), Utami dan Rahmawati (2009).

Hasil penemuan ini berbeda dengan hasil penemuan sebelumnya disebabkan oleh data penelitian yang digunakan dalam penelitian ini berbeda dengan penelitian sebelumnya, Jika penelitian sebelumnya menggunakan laporan tahunan pada periode sebelum diberlakukannya peraturan yang mewajibkan perusahaan untuk melakukan tanggungjawab sosial perusahaan, penelitian ini menggunakan data laporan tahunan pada periode setelah diberlakukannya peraturan oleh pemerintah yang mewajibkan perusahaan melakukan tanggungjawab sosialnya sejak tanggal 23 september 2007 tentang UU Perseroaan terbatas. Hal menyebabkan bahwa pengungkapan informasi sosial perusahaan tidak dipengaruhi oleh kelima variabel diatas yaitu: ukuran dewan komisaris, tingkat leverage, profitabilitas, ukuran perusahaan dan umur perusahaan, 
Namun pengungkapan informasi yang diungkapkan oleh perusahaan karena adanya regulasi pemerintah terhadap pengungkapan informasi sosial perusahaan.

\section{c. Uji Regresi Parsial (Uji t)}

Pengujian ini bertujuan untuk mengetahui hubungan yang signifikan dari masing-masing variabel bebas terhadap variabel terikatnya. Apabila tingkat signifikansi yang diperoleh lebih kecil dari 0,05 maka $\mathrm{H}_{0}$ dapat ditolak atau variabel independen secara statistik mempengaruhi variabel dependen. Dasar pengambilan keputusan : Dengan melihat masingmasing probabilitas signifikansi dari t. Nilai signifikansi masing-masing variabel dapat dilihat pada tabel 4.9 berikut.

Tabel 4.9. Uji Signifikansi Parsial (Uji t)

\begin{tabular}{|c|c|c|c|}
\hline Variabel & Koefisien & t-Statistik & $\begin{array}{c}\text { Signifikansi } \\
\text { Probabilitas }\end{array}$ \\
\hline C & -0.016838 & -0.046035 & 0.9636 \\
\hline X1 & -0.014687 & -0.930755 & 0.3605 \\
\hline X2 & 0.122473 & 0.755386 & 0.4568 \\
\hline X3 & 0.019557 & 1.591834 & 0.1235 \\
\hline X4 & 0.043459 & 2.056792 & 0.0499 \\
\hline X5 & 0.000675 & 0.214224 & 0.8320 \\
\hline
\end{tabular}

Sumber: Data diolah (2011)

Dari tabel diatas dapat dilihat bahwa hasil uji signifikansi secara parsial dapat dijelaskan sebagai berikut:

\section{a. Pengaruh Ukuran Dewan Komisaris terhadap Jumlah Pengungkapan Sosial yang diungkapkan oleh perusahaan}

Berdasarkan tabel 4.9 di atas dapat diketahui bahwa ukuran dewan komisaris $\left(\mathrm{X}_{1}\right)$ menghasilkan nilai thitung sebesar -0.9307 dan memiliki nilai signifikansi probabilitas sebesar 0.3605 lebih besar dari 0.05 yang berarti 
bahwa ukuran dewan komisaris tidak memiliki pengaruh secara parsial terhadap jumlah informasi sosial yang diungkapkan oleh perusahaan. Coller dan Gregory dalam Sembiring (2005) menyatakan bahwa semakin besar jumlah anggota dewan komisaris, maka akan semakin mudah untuk mengendalikan CEO dan monitoring yang dilakukan akan semakin efektif. Dalam penelitian ini melalui analisis $t$, ukuran dewan komisaris yang diproksi dengan jumlah anggota dewan komisaris menunjukkan bahwa tidak ada pengaruh yang signifikan terhadap pengungkapan sosial perusahaan dengan nilai $t=-0.930755$ dan nilai $p=0.3605$. Hasil penelitian ini dapat disimpulkan bahwa menolak $\mathrm{H}_{1}$ dan menerima $\mathrm{H}_{0}$, ini berarti bahwa banyaknya jumlah anggota dewan komisaris dalam suatu perusahaan tidak akan mempengaruhi pengungkapan tanggungjawab sosial yang dibuat perusahaan.

Hasil penelitian ini tidak sejalan dengan penelitian Sembiring (2005), Rosmasita (2007) dan Sitepu (2007) yang berhasil membuktikan adanya pengaruh ukuran dewan komisaris terhadap pengungkapan informasi sosial perusahaan. Variabel ukuran dewan komisaris dalam penelitian ini menunjukkan hubungan negatif terhadap pengungkapan informasi sosial perusahaan dengan nilai koefisien $=-0.014$, hal ini berarti bahwa semakin besar ukuran dewan komisaris akan mengurangi jumlah informasi sosial yang diungkapkan oleh perusahaan, $\mathrm{Hal}$ ini sesuai dengan pendapat Jensen (1993) dalam Linda dan Febrianty ( 2010) yang mengatakan bahwa perusahaan yang memiliki ukuran dewan komisaris yang besar tidak bisa melakukan koordinasi, komunikasi, dan pengambilan keputusan yang lebih baik dibandingkan dengan perusahaan yang memiliki dewan komisaris yang kecil, Hal ini bila dikaitkan dengan jumlah informasi sosial yang diungkapkan perusahaan bahwa semakin besar ukuran dewan komisaris dalam sebuah perusahaan akan menyebabkan berkurangnya jumlah informasi sosial yang diungkapkan oleh perusahaan tersebut, ini disebabkan oleh semakin besar ukuran dewan komisaris maka akan semakin sulit melakukan koordinasi, komunikasi, dan pengambilan keputusan dalam sebuah perusahaan. 


\section{b. Pengaruh Tingkat Leverage $\left(\mathrm{X}_{2}\right)$ Terhadap Jumlah Informasi Sosial Yang diungkapkan oleh perusahaan.}

Berdasarkan tabel 4.9 di atas dapat diketahui bahwa tingkat leverage $\left(\mathrm{X}_{2}\right)$ menghasilkan nilai $\mathrm{t}_{\text {hitung }}$ sebesar 0.7553 dan memiliki nilai signifikansi probabilitas sebesar 0.4568 lebih besar dari 0.05 yang berarti bahwa ukuran dewan komisaris tidak memiliki pengaruh secara parsial terhadap jumlah informasi sosial yang diungkapkan oleh perusahaan.

Perusahaan dengan tingkat leverage yang sangat tinggi memiliki kewajiban untuk melakukan ungkapan yang lebih luas dari pada perusahaan dengan rasio leverage rendah.

Dalam penelitian ini, melalui analisis uji t, leverage yang diproksi dengan rasio hutang terhadap ekuitas tidak menunjukan pengaruh signifikan terhadap pengungkapan sosial perusahaan dengan nilai $\mathrm{t}=0.7553$ dan $p=0.4568$ yang berarti bahwa menolak $\mathrm{H}_{1}$ dan menerima $\mathrm{H}_{0}$. Hasil penelitian ini sejalan dengan Sembiring (2005), Anggraini (2006), Sitepu (2007) dan Rosmasita (2007) yang tidak menemukan adanya hubungan yang signifikan antara tingkat leverage perusahaan dengan jumlah informasi sosial yang diungkapkan. Hal ini dapat disimpulkan bahwa semakin tinggi tingkat leverage semakin besar kemungkinan akan melanggar perjanjian kredit sehingga perusahaan akan berusaha untuk melaporkan laba sekarang lebih tinggi, supaya laba yang dilaporkan tinggi maka perusahaan akan berusaha untuk mengurangi biaya-biaya yang dianggap kurang penting, salah satunya adalah biaya yang berkaitan dengan pengungkapan tanggungjawab sosialnya kepada masyarakat. Hal ini sesuai dengan pendapat Belkaoui \& Karpik (1989) dalam Anggraini (2006) mengatakan bahwa semakin tinggi leverage kemungkinan besar perusahaan akan mengalami pelanggraran terhadap kontrak hutang maka manajer akan berusaha untuk melaporkan laba sekarang lebih tinggi dibandingkan laba di masa depan. Hal ini dilakukan karena perusahaan memiliki kewajiban kepada pihak kreditur untuk melunasi semua kewajiban perusahaannya terlebih dahulu. 


\section{c. Pengaruh Ukuran Perusahaan $\left(\mathbf{X}_{3}\right)$ Terhadap Jumlah Informasi Sosial yang diungkapkan oleh perusahaan}

Berdasarkan tabel 4.9 di atas dapat diketahui bahwa ukuran perusahaan $\left(\mathrm{X}_{3}\right)$ menghasilkan nilai thitung sebesar 1.5918 dan memiliki nilai signifikansi probabilitas sebesar 0.1235 lebih besar dari 0.05 yang berarti bahwa ukuran dewan komisaris tidak memiliki pengaruh secara parsial terhadap jumlah informasi sosial yang diungkapkan oleh perusahaan.

Berbagai penelitian sebelumnya, antara lain yang dilakukan oleh Sembiring (2005) menemukan adanya pengaruh signifikan dari ukuran perusahaan terhadap jumlah informasi sosial yang diungkapkan, secara teoritis perusahaan besar tidak akan lepas dari tekanan, daan perusahaan besar dengan tingkat operasi dan pengaruh yang lebih besar terhadap masyarakat mungkin akan memeilki pemegang saham yang memerhatikan program sosial yang dibuat perusahaan sehingga pengungkapan tanggungjawab sosial perusahaan akan semakin luas.

Dalam penelitian ini, melalui analisis uji, ukuran perusahaan yang diproksi dengan total aktiva tidak menunjukan pengaruh signifikan terhadap pengungkapan tanggungjawab sosial perusahaan dengan nilai $\mathrm{t}=1.5914$ dan $p=0.1235$ yang berarti bahwa menolak $\mathrm{H}_{1}$ dan menerima $\mathrm{H}_{0}$. $\mathrm{Hal}$ ini berarti bahwa besar kecilnya perusahaan tidak mempengaruhi pengungkapan tanggung jawab sosial perusahaan. Hasil penelitian ini berbeda dengan penelitian Sembiring (2005) dan Utami (2009) yang menemukan adanya hubungan yang signifikan antara ukuran perusahaan dengan jumlah informasi sosial yang diungkapkan. Namun penelitian ini sejalan dengan penelitian Rosmasita (2007) dan Sitepu (2007) yang tidak menemukan pengaruh ukuran perusahaan terhadap jumlah informasi sosial yang diungkapkan oleh perusahaan. Dengan demikian dapat disimpulkan bahwa pengungkapan informasi sosial suatu perusahaan tidak terkait dengan besar kecilnya total aktiva yang dimiliki oleh perusahaan, perusahaan tidak mau menjalankan program-program 
tanggungjawab sosial perusahaan karena melihat hal tersebut hanya sebagai pengeluaran biaya (cost center).

\section{d. Pengaruh Profitabilitas $\left(\mathrm{X}_{4}\right)$ Terhadap Jumlah Informasi Sosial Yang diungkapkan oleh perusahaan}

Berdasarkan tabel 4.9 di atas dapat diketahui bahwa profitabilitas $\left(\mathrm{X}_{4}\right)$ menghasilkan nilai $t_{\text {hitung }}$ sebesar 2.0567 dan memiliki nilai signifikansi probabilitas sebesar 0.0499 lebih kecil dari 0.05 yang berarti bahwa profitabilitas memiliki pengaruh secara parsial terhadap jumlah informasi sosial yang diungkapkan oleh perusahaan.

Profitabilitas merupakan faktor yang membuat manajemen menjadi bebas dan fleksibel untuk mengungkapkan pertanggungjawaban sosial kepada pemegang saham. Sehingga semakin tinggi tingkat profitabilitas perusahaan semakin besar pengungkapan informasi sosial. Sebaliknya profitabilitas berpengaruh negatif terhadap pengungkapan tanggung jawab sosial perusahaan. Hal ini didukung dengan argumentasi bahwa ketika perusahaan memilki tingkat laba yang tinggi, perusahaan ( manajemen) menganggap tidak perlu melaporkan hal-hal yang dapat mengganggu informasi tentang sukses keuangan perusahaan.

Dalam penelitian ini, melalui analisis uji $t$, profitabilitas yang diproksi dengan net profit margin menunjukan adanya pengaruh yang signifikan terhadap jumlah informasi sosial yang diungkapkan dengan nilai $\mathrm{t}=2.05679$ dan $p=0.0499$ berarti bahwa menerima $\mathrm{H}_{1}$ dan menolak $\mathrm{H}_{0}$. Hal ini tidak sejalan dengan penelitian Anggraini (2006) dan Sembiring (2005) yang tidak berhasil membuktikan bahwa adanya pengaruh profitabilitas terhadap pengungkapan informasi sosial, Namun penelitian ini sejalan dengan hasil yang ditemukan oleh Sitepu (2009) yang berhasil membuktikan bahwa profitabilitas berpengaruh signifikan terhadap pengungkapan informasi sosial. Hal ini dikarenakan persepsi atau anggapan bahwa aktivitas CSR bukanlah aktivitas yang merugikan dan tidak bermanfaat bagi keberlangsungan perusahaan. Melainkan aktivitas CSR merupakan langkah strategis jangka panjang yang akan memberikan efek positif bagi perusahaan. 
Hasil ini juga mendukung pendapat Heinze (1976) dalam Sitepu (2007) yang menyatakan bahwa dengan semakin tinggi tingkat profitabilitas perusahaan maka jumlah informasi sosial yang diungkapkan juga akan semakin besar.

\section{e. Pengaruh Umur Perusahaan $\left(X_{5}\right)$ terhadap Jumlah Informasi Sosial Yang diungkapkan oleh perusahaan}

Berdasarkan tabel 4.9 di atas dapat diketahui bahwa umur perusahaan $\left(X_{5}\right)$ menghasilkan nilai $t_{\text {hitung }}$ sebesar 0.2142 dan memiliki nilai signifikansi probabilitas sebesar 0.8320 lebih besar dari 0.05 yang berarti bahwa umur perusahaan tidak memiliki pengaruh secara parsial terhadap jumlah informasi sosial yang diungkapkan oleh perusahaan.

Umur perusahaan diperkirakan memiliki hubungan yang positif dengan kualitas ungkapan pertanggung jawaban sosial, alasan yang mendasari adalah perusahaan yang berumur lebih tua memiliki pengalaman yang lebih banyak dalam mempublikasikan laporan keuangan. Perusahaan yang memiliki pengalaman lebih banyak akan mengetahui kebutuhan konsituennya akan informasi tentang perusahaan. Sembiring (2005) juga menjelaskan bahwa Perusahaan yang berumur lebih tua memiliki pengalaman lebih banyak sehingga akan lebih mengetahui kebutuhan konstituennya akan informasi tentang perusahaan. Dengan demikian, umur perusahaan dapat dikaitkan dengan kinerja keuangan suatu perusahaan. Jika suatu perusahaan mempunyai kinerja keuangan yang baik, maka perusahaan tersebut akan dapat menjaga kelangsungan usaha.

Dalam penelitian ini, melalui analisis uji $t$, umur perusahaan yang dihitung sejak tahun perusahaan tersebut berdiri hingga perusahaan tersebut dijadikan sampel dalam penelitian, menunjukan tidak adanya pengaruh yang signifikan terhadap jumlah informasi sosial yang diungkapkan dengan nilai $\mathrm{t}=0.2142$ dan $p=0.8320$ berarti bahwa menerima $\mathrm{H}_{0}$ dan menolak $\mathrm{H}_{1}$. Hal ini tidak sejalan dengan hasil yang ditemukan dalam penelitian Rosmasita (2007) yang berhasil membuktikan bahwa umur perusahaan berpengaruh signifikan terhadap pengungkapan 
informasi sosial, Namun penelitian ini sejalan dengan penelitian Utami (2009), Sembiring (2005), Marwata (2001) yang tidak berhasil membuktikan adanya pengaruh umur perusahaan terhadap jumlah informasi sosial yang diungkapkan perusahaan.

Hal ini dapat disimpulkan bahwa perusahaan yang berumur lebih tua tidak harus melakukan pengungkapan sosial yang lebih besar dibandingkan dengan perusahaan yang terbilang masih berumur muda. Perusahaan yang berumur lebih tua lebih mengerti informasi-informasi apa saja yang sebaiknya diungkapkan dalam laporan tahunan. Sehingga perusahaan hanya akan mengungkapkan informasi-informasi yang dianggap akan memberikan pengaruh yang positif terhadap perusahaan. Dengan demikian perusahaan tidak perlu mengungkapkan semua informasi yang dimilikinya.

Dari uraian di atas dapat diperoleh persamaan regresi berganda sebagai berikut:

\section{$\mathrm{Y}=-0.01683822491-0.01468677268^{\star} \mathrm{X} 1+0.1224731779^{\star} \mathrm{X} 2+$ $0.01955680291^{\star} X 3+0.04345871123^{\star} X 4+0.000674748635^{\star} X 5$}

a. Koefisien konstanta berdasarkan hasil regresi adalah -0.016 dengan nilai negatif, ini dapat diartikan bahwa $Y$ (Pengungkapan sosial) akan bernilai-0.016. KOM, Leverage, Size, Profitabilitas (PM) dan umur perusahaan masing-masing bernilai 0 . Nilai itu berarti pengungkapan tanggung jawab sosial akan ada meskipun tidak dipengaruhi oleh KOM, Lev, Size, dan Pm dan umur perusahaan.

b. Koefisien regresi -0.014 menyatakan bahwa setiap penambahan satu persen variabel dewan komisaris, maka akan mengurangi pula tindakan pengungkapan pertanggungjawaban sosial sebesar 0.014 .

c. Koefisian regresi 0.122 menyatakan bahwa setiap penambahan satu persen variabel Leverage, maka akanmenambah pula tindakan pengungkapan pertanggungjawaban sosial sebesar 0.122 .

d. Koefisien regresi 0.019 menyatakan bahwa setiap penambahan satu variabel Size, maka akan menambah pula tindakan pengungkapan pertanggungjawaban sosial sebesar 0.019 . 
e. Koefisien regresi 0.043 menyatakan bahwa setiap penambahan satu persen variabel Profitabilitas, maka akan menambah pula tindakan pengungkapan pertanggungjawaban sosial sebesar 0.043 .

f. Koefisien regresi 0.0006 menyatakan bahwa setiap penambahan satu persen variabel umur perusahaan, maka akan menambah pula tindakan pengungkapan pertanggungjawaban sosial sebesar 0.0006 .

\section{KESIMPULAN}

Penelitian ini memberikan hasil bahwa ukuran dewan komisaris, tingkat leverage, ukuran perusahaan, profitabilitas dan umur perusahaan secara bersama-sama atau simultan tidak memiliki kemampuan mempengaruhi jumlah informasi sosial yang diungkapkan dalam laporan tahunan perusahaan pertambangan yang terdaftar di Bursa Efek Indonesia. Penelitian ini memberikan hasil bahwa secara parsial, profitabilitas memiliki pengaruh yang signifikan terhadap jumlah informasi sosial yang diungkapkan dalam laporan tahunan perusahaan pertambangan yang terdaftar di Bursa Efek Indonesia. Sedangkan ukuran dewan komisaris, tingkat leverage, ukuran perusahaan dan umur perusahaan tidak berpengaruh signifikan terhadap jumlah informasi sosial yang diungkapkan dalam laporan tahunan perusahaan pertambangan yang terdaftar di Bursa Efek Indonesia.

\section{DAFTAR PUSTAKA}

Alexandri, Moh. Benny.(2008). Manajemen Keuangan Bisnis. Cetakan Kesatu. Alfabeta. Bandung.

Anggraini, Retno. 2006. Pengungkapan Informasi Sosial dan Faktor-faktor yang Mempengaruhi Pengungkapan Informasi Sosial dalam Laporan Keuangan Tahunan (studi empiris pada perusahaan-perusahaan yang terdaftar Bursa Efek Jakarta). Simposium Nasional Akuntansi 9.hal 8-10

Belkaoui,A.R. (2006). Accounting Theory. 5th Ed, Thomson. Jakarta.

Darwin,Ali.(2004). Penerapan Sustainability Reporting di Indonesia, Konvensi Nasional Akuntansi V, Program Profesi Lanjutan, Yogyakarta. Hal. 5-8

Finch,Nigel. (2005). The Motivations for Adopting Sustainability Disclosure. Macquaarie Graduate School of Management. Social Science Research Network. Hal.10 
Fred,Weston, J. dan Eugene Brigham. 2001.Dasar - Dasar Manajemen Keuangan. Edisi 9. Erlangga. Jakarta.

Ghozali, Imam. 2005. Aplikasi Analisis Multivariate dengan Program SPSS. Badan Penerbit Universitas Diponegoro, Semarang.

Gujarati.(2003). Dasar-dasar ekonomitrika.Erlangga. Jakarta

Harahap,Syafri Sofyan (2001). Teori Akuntansi. PT Raja Grafindo Persada, Jakarta.

Hendriksen, Eldon S. dan Michael F. Van Breeda. (2002). Teori akunting. Terjemahan oleh Herman Wibowo. Buku 2. Edisi kelima. Interaksara,Jakarta.

http://202.155.2.90/corporate action/new info jsx/jenis informasi/01 laporan Keuangan/ 02 soft copy laporan keuangan diakses pada pukul 04.35 WIB tanggal 23 Agustus 2011.

http://www.idx.co.id. Diakses, Selasa, 23 Agustus 2011

Ikatan Akuntan Indonesia. (2009). Standar Akuntansi Keuangan. Salemba Empat, jakarta.

Ikhsan Arfan Dan Muhammnad Ishak.(2008). Akuntansi Keperilakuan. Salemba Empat, Jakarta.

Indriyanto,Nur Dan Bambang Supomo (2002). Metodelogi Penelitian Bisnis Untuk Akuntansi Dan Manajemen.Usu Press, Medan

Irawan,Bambang.(2006).Faktor-faktor yang mempengaruhi kelengkapan laporan keuanganpada perusahaan manufaktur yang terdaftar di bursa efek Indonesia (BEI). Universitas Islam Indonesia.Yogyakarta. hal 25.

Komar,Seful.(2004). Akuntansi Pertanggungjawaban Sosial (Social Responsibility Accounting) dan Korelasinya dengan Akuntansi Islam, Media Akuntansi, Edisi 42/Tahun XI, hal. 54-58.

Linda dan Maya Febrianty.(2010). Kinerja Perusahaan dalam Perspektif Agency Theori dan Signaling Theori. Jurnal Ekonomi dan Bisnis,Vol. 9, No 2 Agustus 2010 : 190-202

Lukman,Syamsuddin.(2001). Manajemen Keuangan Perusahaan,PT.Raja Grafindo Persada, Jakarta. 
Marwata. (2001). Hubungan Antara Karakteristik Perusahaan dan Kualitas Ungkapan Sukarela dalam Laporan Tahunan Perusahaan Publik di Indonesia. Simposium Nasional Akuntansi 4.

Masnila,Nelly. (2006). Corporate Social Responsibility : Sebuah Pandangan dari Sudut Akuntansi (Corporate Social Responsibility: An Overview From Accounting Perspective).Hal. 2-3

Nofandrilla.(2008).Analisis Pengaruh Karakteristik Perusahaan terhadap Kebijakan Pengungkapan Tanggung Jawab Sosial (Studi Empiris pada Perusahaan Pertambangan yang Terdaftar di Bursa Efek Jakarta. Skripsi Mahasiswa S1. Surakarta: FE UNS.

Noviyanti,Risca Bernadetta.( 2008). Faktor - faktor Yang Berhubungan Dengan Tanggung Jawab Sosial Perusahaan : Studi Kasus pada PT Indofood Sukses Makmur Tbk. Jurnal akuntansi.

Parker.(1988). The Impact of Corporate Characteristic on Social Responsibility Disclosure.Jurnal akuntansi.hal.30-33

Rosmasita,Hardhina.(2007).Faktor-faktor yang Mempengaruhi Pengungkapan Sosial (Social Disclosure) dalam Laporan Tahunan pada Perusahaan yang Terdaftar di Bursa Efek Indonesia. Jurnal Akuntansi. Hal.25-30.

Saidi.(2004). Faktor-faktor yang Mempengaruhi Struktur Modal Pada Perusahaan Manufaktur Go Public Di BEJ Tahun 1997-2002. Jurnal Manajemen.hal. 20.

Santoso,Singgih.(2007). Panduan Lengkap Menguasai SPSS16. PT.Elex Media Komputindo,Jakarta.

Sembiring,Eddy.(2005). Karakteristik Perusahaan dan Pengungkapan tanggung Jawab Sosial : Study Empiris Pada Perusahaan yang tercatat di Bursa Efek Jakarta, Simposium Nasional Akuntansi. Vol.19. hal. 38-40.

Sitepu, Andre Christian.(2007). Faktor-Faktor Yang Mempengaruhi Pengungkapan Informasi Sosial Dalam Laporan Tahunan Pada Perusahaan Manufaktur Yang Terdaftar Di Bursa Efek Jakarta. Jurnal akuntansi vol.19. Hal.22-30.

Sugiyono.(2004). Metode Penelitian Bisnis, Alfabeta, Bandung.

Umar, Husein.(2006). Metodelogi Penelitian. Raja Grafindo, Jakarta

Utami, Indah Dewi dan Rahmawati.(2009). Pengaruh Ukuran Perusahaan, Ukuran Dewan Komisaris, Kepemilikan Institusional, Kepemilikan Asing, Dan Umur Perusahaan Terhadap Corporate Social Responsibility Disclosure Pada 
Perusahaan Property Dan Real Estate Yang Terdaftar Di BursaEfek Indonesia, Surakarta. Hal.5-10

Wahyudi, Johan.(2010). Pengaruh Pengungkapan Good CorporateGovernance, Ukuran Dewan Komisaris dan TingkatCross Directorship Dewan Terhadap NilaiPerusahaan, Semarang. hal. 24

Widiastuti, Harjanti.(2002). Pengaruh Luas Ungkapan Sukarela dalam Laporan Tahunan terhadap Earning Response Coefficient (ERC).Simposium Nasional Akuntansi V, Semarang.hal. 5-6

Winarno, W. Wahyu (2007), Analisis Ekonometrika dan Statistika dengan Eviews, UPP STIM YKPN 